\title{
IMAGINATION AND AMBITION OF CHILDREN CHARACTER IN J.K. ROWLING NOVEL HARRY POTTER AND THE ORDER OF PHOENIX (2003)
}

\author{
Rahmah Nurul Aziz ${ }^{1}$, Yuyun Nurulaen ${ }^{2}$, and Pepen Priyawan ${ }^{3}$ \\ Tk It Nurul Bahjah Cianjur ${ }^{1}$, \\ Universitas Islam Negeri Sunan Gunung Djati Bandung ${ }^{2}$ \\ Universitas Islam Negeri Sunan Gunung Djati Bandung ${ }^{3}$
}

\begin{abstract}
Every parent has high hopes for their children. They will protect their children from a bad environment to keep them from behaving badly too. This is also because their minds will be influenced by the environment in which they grow and develop. Because this research is based on literature, the researcher uses literary devices to support good and accurate research. Therefore, this paper uses qualitative research that provides description of the phenomena. For more technical analysis on the comparison of the data taken from the novel, this research uses comparative literature method. The results show that novel Harry Potter and The Order of Phoenix presents clearly the struggle of Harry and his friends to defeat Voldemort and his followers. Therefore, after the death of his parents, Harry was entrusted to a good family and an environment filled with people who really care about him. Imagination and ambition will be created on the basis of the thoughts of the doer. Therefore, the development of character in terms of ambition and imagination was found in the novel.
\end{abstract}

Keywords: Literature, Children Character, Imagination, Ambition

\section{INTRODUCTION}

Children literature is a literary work in which the work can be enjoyed by children and young people. Children literature usually focuses on simple stories to provide clear information that reaches the audience. Children literature can be in the form of storybooks in the form of magazines or fairy tales and the stories made in these stories are interesting topics among the children's ages. In addition to the form of books and texts, in modern times, children's literary works can be in the form of film or song that is adjusted based on the age of the children who listen to it. Also, the themes taken are also increasing, for example, by the existence of elements of fantasy, myth, and magic as supporting stories. Literary works that carry the matter about myth and magic are not just objects chosen by many researchers. Some of literary works with the theme of magic and myth are the lord of the ring and Percy Jackson, both of them raised the theme of magic and myths. Therefore, the researcher focuses on children's literary works and only refer to children. As mentioned by researchers regarding children's literary works that develop over time, the object of this research is novel Harry Potter and The Order of Phoenix (2003) written by J.K. Rowling. In this harry potter book, Rowling adds extrinsic elements to support the whole harry potter story. The elements included are myth and magic. In addition to taking the topic of harry potter as research material, researchers also 
took the film beyond the blackboard (2011) produced by American director Jeff Bleckner, this film tells about the lives of children in the salt lake area where the majority of the population does not have a house or a system economy and low education. This story is based on the original experience of the author of the book himself. In this story there are extracurricular elements that must be underlined in the story beyond the blackboard itself is the historical and biographical elements of the author himself in this story.

Novel is an invented prose narrative of considerable length and certain complexity that deals imaginatively with human experience. This is based on Stacey Bess experiences in her past. Usually through a connected sequence of events involving a group of persons in a specific setting. Within its broad framework, the genre of the novel has encompassed an extensive range of types and styles: picaresque, epistolary, Gothic, romantic, realist, historical - to name only some of the more important ones (Abrams, 1999).

The novel can also be made through the imagination of the writer based on the mindset of the writer; this is related to the creativity of the writer in expressing the story that he will write. In writing stories in all novels, it is supported by intrinsic elements in order to build stories that have good quality and deserve to be enjoyed by every circle. Within the scope of literature and outside literature.

Every human being has the imagination and ambition to make their lives well. Usually the imagination will be experienced by children because their minds and sub-consciousness are still pure and broad, so the children always imagine things that might not happen. But it's different from ambition. Every ambition will be owned by the human layer, because ambition is the same as the characteristics, desires and passion where it aims to reach what someone wants. The ambition created can be influenced by the social environment in which the children live, this is synonymous with the mindset and lifestyle of the children based on their environment, if good, then the mind is good, if the children's environment is far from decent, then the mind they will be polluted (Shilling \& Mellor, 2001). Slightly different from ambition, imagination is actually a mind game formed through the desires of the mind owner. Imagination is also a work of reason in developing a thought that is broader than anything that has ever been seen, heard and felt. With imagination, humans develop something from simplicity to value in the mind. $\mathrm{He}$ can develop something created by God in his mind with the aim of developing something more valuable in the form of objects, or just thoughts that cross the mind (Beaney, 2010).

In this research, researchers will take the characters in the novel as the main object of research. Based on the explanation that the researchers discussed above, this research concerns the imagination and ambition of children. Therefore, the character of children is a pillar in this research. Children's characters are different from characters in general. Child character means making children as one of the important cores in a storyline. A common concern of character in children literature is the growth of the child character into maturity or significant step taken towards independence. Such change during the duration of the story is called character development (Gamble \& Yates, 2002). Based on the description of Gamble and Yates, the character of the children will change as the story goes on. In addition, the characters must have a good impact on the audience (Abrams, 1999). It is well known that children will always catch what is shown to them so that any work devoted to children is required to have a good impact for these children. 


\section{LITERATURE REVIEW}

This section presents several previous studies or previous studies that have relevance to this research. The first study was conducted by Purwati (2009) with the title "The struggle of three women characters under patriarchal system in Bronte's Wuthering Height (a case study of Feminist Literary Theory)." The research conducted by Pratiwi focuses on comparison of characters in Emely Bronte's Wuthering Height and studied through feminist theory. This research concerns the feminist topic that the researcher took. It is the same case with the researchers. In this research, the researcher compares the characters created by the two researchers above who clearly have their own views on literary works which are motivated by the social life of the researcher.

The second study was conducted by Nurhakim with the title "The Characterization of Iris from Ignorant to Well Care Family in Agatha Christie's Sparkling Cyanide". The research conducted by Nurhakim focuses on the change in character found in the novel by Agatha Christie entitled Sparkling Cyanide.

The third study was conducted by Ardliati with the title "Children Imagination in Shalmanrushi's Midnight Children". The researcher uses the same topic and theory about imagination from Warnock's definition. In addition, the researcher uses children's literature as main object for this research.

The contents of this journal refer to the development of character education carried out by the American government. Where they use an approach through moral learning without seeing the old tradition or the education system. Because as is known this character education system was crowded in the years around 1940s and 1960s.

This journal helps researchers to measure the extent of the role of the education system which, if encouraging many things, motivates students to improve the new generation.

Furthermore, the researcher added a thesis by Rima Andini entitled the similarities and differences of five typical characters in William Sweet of Bird of Youth and the Glass Menagerie as one of the references in this study because the research conducted by researchers has similarities with the thesis done by Andini, namely, the similarities and differences that exist in a literary work, therefore researchers make this scientific work as a reference.

\section{METHOD}

This research is qualitative research. Qualitative research is research that presents explanations in the form of descriptions of the data obtained. Qualitative method is basically the same as the hermeneutic method. This means that both the hermeneutic, qualitative, and content analysis methods, as a whole, make use of ways of interpretation by presenting them in the form of descriptions (Ratna, 2004). This method is carried out to describe the facts which are then followed by analysis.

According to Donald Ary (2004), basic interpretative study provides descriptive accounts targeted to understanding a phenomenon using data that might be collected in a variety of ways, such as interviews, observations, and document review. The purpose is to understand the world or experience of another. These are the simplest and the most common qualitative studies. Describing how teachers perceive their role in selecting curriculum is an example (Ary, Jacobs, \& Sorensen, 2006). 
This method will be used to describe what belongs to the imagination and ambition of the works that are the topic of research, namely J.K. Rowling's Harry Potter novels and the Order of the Phoenix (2003) and Stacey Bess Movie Beyond on the Blackboard (2011) each work will be described first and then analyzed through the entire data and assisted with the theories described above.

Specifically, comparative literature method is a method of comparison, whether similarities or differences that stand out in a literary work. The comparison is not limited to how much a literary work. In accordance with the quote According to Susan Bassnett in his book Comparative Literature: A Critical Introduction

\footnotetext{
"Comparative Literature is the study of literature beyond the confines of one particular country, and the study of the relationships between literature on the one, and other areas of knowledge and belief, such as the arts (e.g painting, sculpture, architecture, music), philosophy, history, the social sciences (e.g politics, economics, sociology) the sciences, religion, etc" (Bassnett, 1993, hal. 31)
}

In accordance with the above quote, the researcher has the right to choose and determine whatever literary work is needed. Because according to Basnet, any of her work is not a problem as long as it has the same plot, not a single event. The vastness of the area that can be compared makes this research related to religion because it discusses the figure of Muhammad who is a Muslim religious figure. Then the breadth of comparative research involves film, song and biography.

\section{FINDINGS AND DISCUSSIONS}

In the harry potter novel, J.K. Rowling shows some scenes about the imagination and ambition by Harry's character and his friends in their respective ways. In harry potter, the researcher found significant imagination and ambition. In finding imagination and ambition, the researchers focused this research on the character of children to support the topics previously mentioned. Imagination and ambition have close links with humans, because as is known from the above-quoted theory that the imagination of ambition funds is created based on the human mind itself. Harry potter carries the theme of children's literature; therefore, the characters are played using a cast that is still a child and the characters are still children. Besides setting the location used in this story with a school setting, the smiling school is a magic school called Hogwarts.

The character of the child himself is based on the theory expressed by Nikki Gamble and Sally Yates

"A common concern of children's fiction is growth of a child character into maturity or significant steps taken towards independence. Such change brought about during the duration of the story is called character development." (Gamble \& Yates, 2002)

From the exposure to the above-quotation, it is understood that the characters contained in children's literature have a slight difference from the characters in the other rich. Like a quote that says that the character of a child will turn into more mature as the story goes on. Other than that, the character in the story must have a good effect other than because it has to be like that, this is because the story was made to make children interesting in reading or enjoying it.

In analyzing imagination and ambition of children characters. The researcher found a dialog or narration in harry potter and the order of phoenix which arranged the event to get imagination and ambition inside the story. The imagination and 
ambition were found in dialog and narration collected from the whole story and also from the situation and condition of each character.

Table 1. The Display of the Data of Research

\begin{tabular}{|c|c|c|}
\hline Events & $\begin{array}{l}\text { Imagination and } \\
\text { Ambition }\end{array}$ & pages \\
\hline $\begin{array}{r}\text { The } \\
\text { first event }\end{array}$ & $\begin{array}{l}\text { Ambition } \\
\text { Harry potter } \\
\text { "The madhouse has } \\
\text { chucked me out," said Harry. } \\
\text { "So I can do whatever I like. } \\
\text { You've got three seconds. One } \\
\text { - two -" }\end{array}$ & 28 \\
\hline $\begin{array}{c}\text { The } \\
\text { second event }\end{array}$ & $\begin{array}{l}\text { "I want to know what's } \\
\text { been going on," Harry said at } \\
\text { once. He did not look at Mrs. } \\
\text { Weasley. He had been touched by } \\
\text { what she had said about his } \\
\text { being as good as a son, but he } \\
\text { was also impatient at her } \\
\text { mollycoddling. . . . Sirius was } \\
\text { right, he can handle this. (pg. 90) } \\
\text { "Why not?" said Harry } \\
\text { quickly. "I'll join, I want to join, } \\
\text { I want to fight - "(pg. 95) }\end{array}$ & 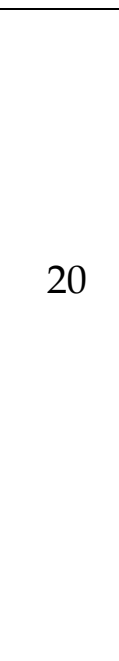 \\
\hline & & 95 \\
\hline $\begin{array}{l}\text { The } \\
\text { third event }\end{array}$ & $\begin{array}{l}\text { "Expelliarmus!" said } \\
\text { Neville, and Harry, caught } \\
\text { unawares, felt his wand fly out } \\
\text { of his hand. "I DID } \\
\text { IT!" said Neville } \\
\text { gleefully. "I've never done it } \\
\text { before - I DID IT!" (pg. 323) }\end{array}$ & 323 \\
\hline $\begin{array}{c}\text { The } \\
\text { fourth event }\end{array}$ & $\begin{array}{l}\text { Imagination } \\
\text { "And what good's } \\
\text { theory going to be in the real } \\
\text { world?" said Harry loudly, his } \\
\text { fist in the air again. Professor } \\
\text { Umbridge looked up. "This is } \\
\text { school, Mr. Potter, not the real } \\
\text { world," she said softly. "So } \\
\text { we're not supposed to be }\end{array}$ & 244 \\
\hline
\end{tabular}




\begin{tabular}{|c|c|c|}
\hline & $\begin{array}{l}\text { prepared for what's waiting } \\
\text { out there?" "There is nothing } \\
\text { waiting out there, Mr. Potter." }\end{array}$ & \\
\hline $\begin{array}{l}\text { The } \\
\text { fifth event }\end{array}$ & $\begin{array}{l}\text { He let out a long, slow } \\
\text { breath and stared up at the } \\
\text { brilliant blue sky. Every day } \\
\text { this summer had been the } \\
\text { same: the tension, the } \\
\text { expectation, the temporary } \\
\text { relief, and then mounting } \\
\text { tension again ... and always, } \\
\text { growing more insistent all the } \\
\text { time, the question of why } \\
\text { nothing had happened yet... } \\
\text { pg }\end{array}$ & 5 \\
\hline $\begin{array}{r}\text { The } \\
\text { sixth event }\end{array}$ & $\begin{array}{l}\text { These furious thoughts } \\
\text { whirled around in Harry's } \\
\text { head imajinasi, and his insides } \\
\text { writhed with anger as a sultry } \\
\text { ambisi sudut pandang, velvety } \\
\text { night fell around him, the air } \\
\text { full of the smell of warm, dry } \\
\text { grass symbol and the only } \\
\text { sound that of the low grumble } \\
\text { of traffic on the road beyond } \\
\text { the park railings. }\end{array}$ & 10 \\
\hline $\begin{array}{c}\text { The } \\
\text { seventh event }\end{array}$ & $\begin{array}{l}\text { They had finally started } \\
\text { work on Patronuses, which } \\
\text { everybody had been very keen to } \\
\text { practice, though as Harry kept } \\
\text { reminding them, producing a } \\
\text { Patronus in the middle of a } \\
\text { brightly lit classroom setting } \\
\text { tempat when they were not under } \\
\text { threat was very different to } \\
\text { producing it when confronted by } \\
\text { something like a dementor. } \\
\text { Neville was having trouble too. } \\
\text { His face was screwed up in } \\
\text { concentration, but only feeble } \\
\text { wisps of silver smoke issued from } \\
\text { his wand tip. "You've got to think } \\
\text { of something happy, imajinasi" } \\
\text { Harry reminded him. "I'm trying, } \\
\text { ambisi" said Neville miserably, } \\
\text { who was trying so hard his round } \\
\text { face was actually shining with } \\
\text { sweat. }\end{array}$ & 506 \\
\hline
\end{tabular}


The table above describes the imagination and ambition in literary work with title Harry Potter and The Order of Phoenix. Particularly, the dialogue of each children character in story explains the imagination and ambition through the situation and condition of the characters themselves.

Without the characters, then a story will not go well. Fiction is different from biography or autobiography. In a fictional story, the writer needs characters to make the story work. The characters themselves who will make an event look more real are supported by the dialogue within it (Hunt P., 2004). In accordance with the title chosen by J.K. Rowling herself, Harry Potter is the main character of this story, or the holder of the story. This means that all events contained in the storyline will always be related to Harry Potter and his friends. Even so the story will not work if there is only Harry character in it. Characters like protagonists, antagonists is necessary to be able to make stories more interesting. Each character is given a role. Regarding uncle Vernon, he is a person who hates differences, so he hates Harry because Harry is a group of magicians, whereas they are ordinary people. There is in the quotation 'I will not tolerate mention of your abnormality under this roof'. The characters from the Dusley family themselves will say Harry to remain strong and strong. There are Ron and Hermione who can be said to be Harry's accomplices in every event experienced by Harry. Both have important roles in the story because they are Harry's best friends. The appearance of the two causes different sensations for the reader. Then there was the chancellor of the Hogwarts teachers who was glad to be at Harry's side replacing his parents, the professors and the Dumbledore album that always gives Harry strength. Then the antagonist character is Voldemort. Characters have two kinds. The first is static, then the second is dynamic. Static characters are characters that do not change from the beginning of the story until the end of the story, but dynamic characters will change along with the storyline. Harry is a static character but Voldermort is a dynamic character because initially he is a good character, but he changes when he has a bad family. The above quote can be said to be Harry who is imagining how Harry thinks and talks to himself without saying anything. He felt anxious, bored and disappointed with his situation in words of expectation. Expectation itself is the same as expecting things that haven't really happened.

The novel needs 3-4 characters to support the course of the story, but only one is the main character and the holder of the story. This is used to make each character, protagonist and antagonist have followers because each character will form other plots and be concerned with both parties. For example, each character of the protagonist is told about the past as well as the antagonist character. The story of Harry Potter, J.K. Rowling has the clear and detail past of Harry Potter because Harry Potter himself is the main holder of the storyline. On the other hand, Rowling also tells about voldermort who is the antagonist character of the story, even so J.K. Rowling limits the story between Harry Potter and Voldemort. Voldemort and Harry have a clear connection, even though both are opposing characters. Concerning the narration above, J.K Rowling shows the elements related to imagination and ambition through several acts chosen by J.K. Rowling some of them are these furious thoughts whirled around in Harry's head furious thought. It refers to Harry's mind, which is not conveyed. It means that imagination cannot always be shown through an act, but rather over-thinking about things that have not yet happened to (Gündoğan, Ari, \& Gönen, 2013) then the next sentence and his insides writhed with 
anger as a sultry. This shows the ambition side that exists in Harry, the agreement was taken because Rowling included inside and anger. This shows the race of anger and lust for Harry cousin Dudley who always corners Harry and his family who are half blood, which is half human and half magician. According to Shilling and Mellor (2001), ambition can be either good ambition or bad ambition, this refers to how the environment around him. In this case Harry is eager to hit Dudley and his friends because he insulted Harry's family with dirty words. But on the other hand, he held back his anger by trying to be calm and control his emotions. The sentences that Rowling chooses to shape and illustrate the imagination and ambition can be seen through the characters of Harry and Dudley.

\begin{tabular}{|l|c|}
\hline Characters & Imagination and Ambition's \\
\hline Harry Potter & I can do \\
\hline Neville Longbottom & I want to fight \\
\hline Harry Potter & I DID IT!! \\
\hline Harry Potter & $\begin{array}{c}\text { And what good's theory } \\
\text { going to be in the real world?" } \\
\text { "You've got to think of } \\
\text { something happy, }\end{array}$ \\
\hline Heville Longbottom & I'm trying, \\
\hline
\end{tabular}

From the table above, the researcher tries to explain briefly and concisely the imagination and ambition expressed by each character through the literary dialogue tool. In addition, the delivery can be conveyed through the narrative presented by the writer of the story itself.

\section{CONCLUSIONS}

Based on the discussion, the researcher concluded that imagination and ambition mostly appears from the intrinsic element. Most of those elements are literary devices, especially characters. As the result, the researcher got seven events of imagination and ambition related to each other. This shows that imagination and ambition are related to human mind. Also, it can be found that imagination and ambition are also affected by social life, moral life, and the environment where the children live. Children's mind is innocent and pure. That is why children will always think about something good, such as Harry Potter in this story. Harry Potter lives where people care deeply about him, even though his parents have died as a result of being killed by Voldemort. However, it only causes a feeling of wanting to kill Voldemort, but Harry has to fight very hard to protect those who have been by his side until the end. 


\section{REFERENCES}

Abrams, M. H. (1999). A Glossary of Literary Term. US: HEINLE AND HEINLE Thomson Learing.

Ary, D., Jacobs, L. C., \& Sorensen, C. K. (2010). Introduction to Research in Education. USA: Wadsworth, Cengage Learning.

BEANEY, M. (2010). Imagination andCreativity. The Open University Walton Hall, Milton Keynes : United Kingdom.

Carruthers, P. (2002). Human Creativity: Its Cognitive Basis, Its Evolution, and Its Connections with Childhood Pretence. British Journal for the Philosophy of Science, 53(2), 225-249.

Gamble, N., \& Yates, S. (2002). Exploring Children's Literature Teaching the Language and Reading of Fiction. London: A SAGE Publications Company .

Hogan, R., Jones, A. B., \& Sherman, R. A. (2014). Where is Ambition in Factor Models of Personality? ambition, 1-27.

Hunt, P. (2004). International Companion Encyclopedia of Children's Literature. London: Routledge.

Shilling, C., \& Mellor, P. A. (2001). The Sociological Ambition. London: SAGE Publications . 